\title{
IN VITRO SELECTION ON FUSARIC ACID OF Vanilla planifolia PLANTLETS FOR OBTAINING A CULTIVAR, WHICH RESISTANT TO Fusarium oxysporum f. sp. vanillae
}

\author{
Nurcahyani, E. ${ }^{1}$, Suharyanto, E. ${ }^{2}$, Hadisutrisno, B. ${ }^{3}$, Sumardi, I. ${ }^{2}$ \\ ${ }^{1}$ Dept of Botany, The Faculty of Mathematics and Natural of Science, Lampung University \\ ${ }^{2}$ Laboratory of Plant Structure and Development, Faculty of Biology, Gadjah Mada University \\ ${ }^{3}$ Dept of Plant Disease, The faculty of Agriculture, Gadjah Mada University \\ E-mail: endang_nurcahyani@yahoo.com
}

\begin{abstract}
The most production constrain on Vanilla planifolia Andrews plantation recently has been caused by foot rot disease that later influence in decreasing the yield product. This disease is caused by Fusarium oxysporum f. sp. vanillae (Fov). So far, the disease has not been successfully prohibited although some experiments had been conducted. The use of foot rot resistant cultivar has been introduced, which expected has high yield as one alternative method for controlling this disease. A resistant vanilla plantlet to Fov has been initiated by in vitro selection on MS medium containing fusaric acid (FA) on selective concentration. The purpose of research were to study and determine: 1) The proper combination of 2,4-D and NAA for callus initiation and shoot development from shoot tip explants, along with proper concentration of BAP for shoots initiation from nodal explants; 2) The FA concentration of plantlet selection tolerant to steady growth;3) The proper concentration of FA for in vitro selection for suppressing the Fov. Results showed that: 1) the proper concentration of both combination between $2,4-\mathrm{D}$ and NAA is about $2,0 \mathrm{mg} / \mathrm{L}$ and $10 \mathrm{mg} / \mathrm{L}$ respectively for callus initiation and shoot development from shoot tip explants; also the BA concentration is $1,0 \mathrm{mg} / \mathrm{L}$ for shoot initiation from a nodal explants; 2) the FA tolerant concentration for plantlet selection with vanilla steady growth is between $90 \mathrm{ppm}-110 \mathrm{ppm}$; 3) the $110 \mathrm{ppm}$ of FA was effective for suppressing the Fov compared to $90 \mathrm{ppm}$ and $100 \mathrm{ppm}$ respectively.
\end{abstract}

Key words: Vanilla planifolia Andrews, the vanilla foot rot disease, Fusarium oxysporum f.sp. vanillae, in vitro, fusaric acid

\section{INTRODUCTION}

Vanilla is one of export commodities industry in Indonesia foreign exchange. Market demand of Indonesian vanilla had been considerable because it has high levels of vanillin about $2,75 \%$. The foot rot disease on vanilla is the most crucial disease caused by Fusarium oxysporumf. sp. vanillae (Fov), which is the most limitation and up to know days is not well managed yet. One an alternative way to control foot rot disease could be done by using a cultivar, which is resistant to this disease. In order to gets a new vanilla cultivar, which resistant to BBV by using an in vitro selection method on medium containing fusaric acid.

\section{MATERIALS AND METHODS}

Materials used for this research including: Laminar Air Flow Cabinet (LAF), autoclave, Whatman filter paper no 1 and 42, syringe filter with diameter of 0,45 $\mu \mathrm{m}$ and 0,22 $\mu \mathrm{m}$, culture flasks $500 \mathrm{~mL}$, digital Canon Ixus $951 \mathrm{~S}$ camera. Vanilla planifolia in vitro Plantlet, fusaric acid from Sigma chemical Co., Naphthalene Acetic Acid (NAA), 2,4Dichlorophenoxy Acetic Acid (2,4-D), Benzine Amino Purine (BAP), Plant Preservative Mixture (PPM), and MS (Murashige \& Skoog) solid ready used medium. 
Preliminary study was done on in vitro regenerated vanilla plantlet by using different explants, planted on the medium containing such a plant growth regulators. Whereas these 2,4-D, NAA and BAP as plant growth substances were used in this research. Vanilla plantlet was selected with fusaric acid (AF) supplementation to MS solid medium in different concentration $(0,90,100,110$ and $120 \mathrm{ppm})$ for 12 weeks. Resistant plantlet has already proof when spores of microconidium Fov. had infected to plantlet didn't affected on this in vitro plantlet respectively and this result supported by Hadisutrisno (2004).

Qualitative information as the result on this research was consisted as narratives descriptive and supported by photographs. After that, data's were statistically analyzed by Completely Randomized Design. As quantitatively data's from each parameter measured, were compiled and statistically analyzed by analysis of variance (ANOVAs). If the result showed a significantly different, then was continued analyzed by using Duncan Multiple Range Test (DMRT) analysis with accuracy $95 \%$.

\section{RESULTS AND DISCUSSION}

The results showed that a combination of 2,4-D 2,0 mg/L plus NAA $10 \mathrm{mg} / \mathrm{L}$ was the best callus for initiation and development of shoot from shoot tip explants and the BA $1,0 \mathrm{mg} /$ $L$ is the best for shoot initiation from a nodes explants. Vanilla plantlet regeneration was the best results obtained by using nodal explants. In one node explants which produced from 3 up to 6 shoots within 12 weeks (Figure 1). Capability in nodal explants forming a shoot arising due to axillaries meristem consisted in the stem, so explants easily regenerate to form a shoot (Neelannavar, 2006).

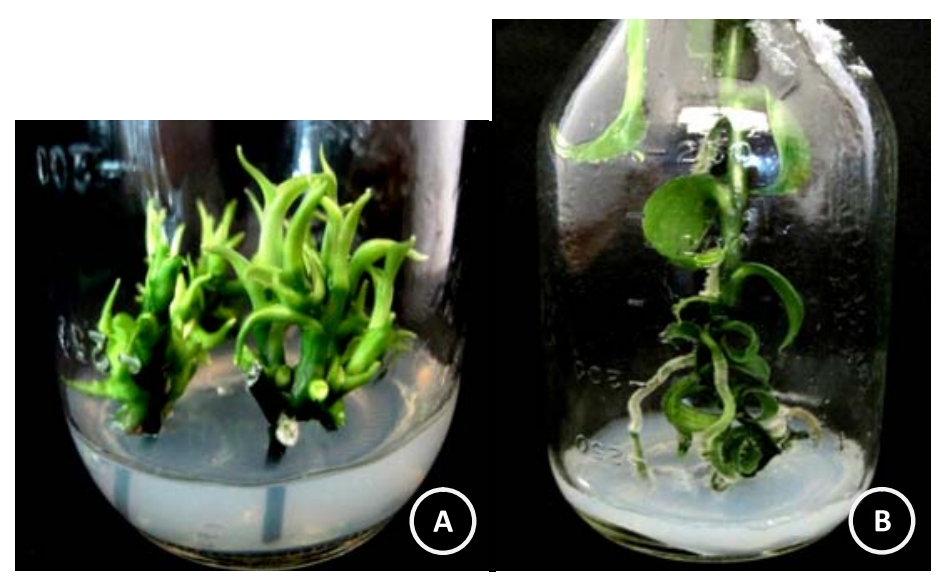

Figure 1. Plantlet regeneration from stem nodes explants Vanilla planifolia Andrews on MS medium $+\mathrm{P} 1 \mathrm{mg} / \mathrm{L}$ of Benzyne Amino Purin. $A=12$ week of plantlet, $B=32$ weeks of plantlet.

The tolerant FA concentration on plantlet selection with vanilla steady growth was between $90 \mathrm{ppm}-110 \mathrm{ppm}$. They showed yields in plantlet vanilla at about 17,14\% (90 ppm), $12,00 \%$ (100 ppm) and 10,59 \% (110 ppm), all of them insensitive to FA (Table 1) Phenotype plants insensitive toward FA may occurred as a result of peroxides enzymes on plant variants that detoxification toxins (Jayasankar et al., 2000; Saravanan, 2004; Svabova \& Lebeda, 2005). 
Table 1. Percentage of Vanilla plantlet number, which still survive on multiplication medium

\begin{tabular}{cccccc}
\hline $\begin{array}{c}\text { Konsentrasi } \\
\text { AF }\end{array}$ & \multicolumn{5}{c}{ Percentage of Vanilla plantlet number in different weeks } \\
\cline { 2 - 6 }$(\mathbf{p p m})$ & $\mathrm{I}$ & $\mathrm{II}$ & $\mathrm{III}$ & $\mathrm{IV}$ & XII \\
\hline $\mathbf{0}$ & 100,00 & 100,00 & 100,00 & 98,89 & 88,89 \\
$\mathbf{9 0}$ & 27,14 & 25,00 & 25,00 & 23,57 & 17,14 \\
$\mathbf{1 0 0}$ & 14,00 & 14,00 & 14,00 & 13,00 & 12,00 \\
$\mathbf{1 1 0}$ & 12,94 & 12,94 & 12,94 & 12,94 & 10,59 \\
\hline
\end{tabular}

By using FA concentration of 110 ppm was effective for suppressing the growth of Fov, by declined intensity up to $25 \%$, compared to the concentration of $90 \mathrm{ppm}$ and $100 \mathrm{ppm}$ respectively. In other words by using 110 ppm fusaric acid could increased the category criteria to resistant (Table 2). This result was also supported by Agrios (2005), which showed that respond of FA selection would affect declined of pathogenic intensity in this case by Fov.

Tabel 2. Pathogenic Intensity result from defend and level vanilla at different fusaric acid concentration treatment.

\begin{tabular}{|c|c|c|c|c|c|c|c|c|}
\hline \multirow{3}{*}{ treatment } & \multicolumn{8}{|c|}{ Day observation } \\
\hline & \multicolumn{2}{|r|}{5} & \multicolumn{2}{|r|}{13} & \multicolumn{2}{|c|}{21} & \multicolumn{2}{|c|}{29} \\
\hline & $\begin{array}{l}\text { IP } \\
(\%)\end{array}$ & $\begin{array}{l}\text { resistant } \\
\text { category }\end{array}$ & $\begin{array}{l}\text { IP } \\
(\%)\end{array}$ & $\begin{array}{l}\text { resistant } \\
\text { category }\end{array}$ & $\begin{array}{c}\text { IP } \\
(\%)\end{array}$ & $\begin{array}{l}\text { resistant } \\
\text { category }\end{array}$ & IP (\%) & $\begin{array}{l}\text { resistant } \\
\text { category }\end{array}$ \\
\hline $0 \mathrm{ppml}$ & 62,50 & sensitive & 91,67 & sensitive & 93,75 & sensitive & 100,00 & sensitive \\
\hline 90 ppm & 31,25 & Moderate & 33.33 & Moderate & 41,67 & Moderate & 50,00 & Moderate \\
\hline 100 ppm & 33,33 & Moderate & 41,67 & Moderate & 50,00 & Moderate & 50,00 & Moderate \\
\hline 110 ppm & 00,00 & resistant & 25,00 & resistant & 25,00 & resistant & 25,00 & resistant \\
\hline
\end{tabular}

note: IP= Pathogenic Intensity

\section{ACKNOWLEDGMENT}

This research was supported by the grant of Doctor Dissertation programmed, DIPA Gadjah Mada University, with Contract No. LPPM-UGM/894/BID.I/2011 at 21 April 2011. Thanks for BPPS Scholarship from High Education Level Directory of National Department Education and Cultural. Thanks also for plantlet of Vanilla planifolia Andrews, as plant material from Unit Pelaksana Teknis (UPT) Dinas Pertanian, Perkebunan dan Kehutanan, Kabupaten Magelang.

\section{REFERENCES}

Agrios, G.N. 2005. Plant Pathology. $5^{\text {th }}$ Ed. Academic Press. New York. 922 p. Hadisutrisno, B. 2004. Taktik dan Strategi Perlindungan Tanaman Menghadapi Gangguan Penyakit Layu Fusarium. Simposium Nasional I, 2-3 Maret 2004 di Purwokerto. Jayasankar, S., Z. Li, and D.J. Gray. 2000. In Vitro Selection of Vitis vinifera 'Chardonnay' with Elsinoe ampelina Culture Filtrate is Accompanied by Fungal Resistance and Enhanced Secretion of Chitinase. Planta. 211: 200-208.

Neelannavar, V.S. 2006. In vitro Propagation Studies on Vanilla (Vanilla planifolia Andr.). Department of Horticulture College of Agriculture, Dharwad University of Agricultural. Thesis. Dharwad. India. 
Saravanan, T., R. Bhaskaran, and M. Muthusamy. 2004. Pseudomonas fluorescens Induced

Enzymological Changes in Banana Roots (Cv. Rasthali) against Fusarium Wilt Disease. Plant Pathology Journal 3: 72-80.

Svabova, L., and A. Lebeda. 2005. In vitro Selection for Improved Plant Resistance to ToxinProducing Pathogens. J. Phytopathol 153: 52-64. 